\title{
SPECIALITIES IN THE INSTITUTIONALISATION OF HUNGARIAN LEADER LOCAL ACTION GROUPS
}

\author{
Csaba Patkós ${ }^{1}$
}

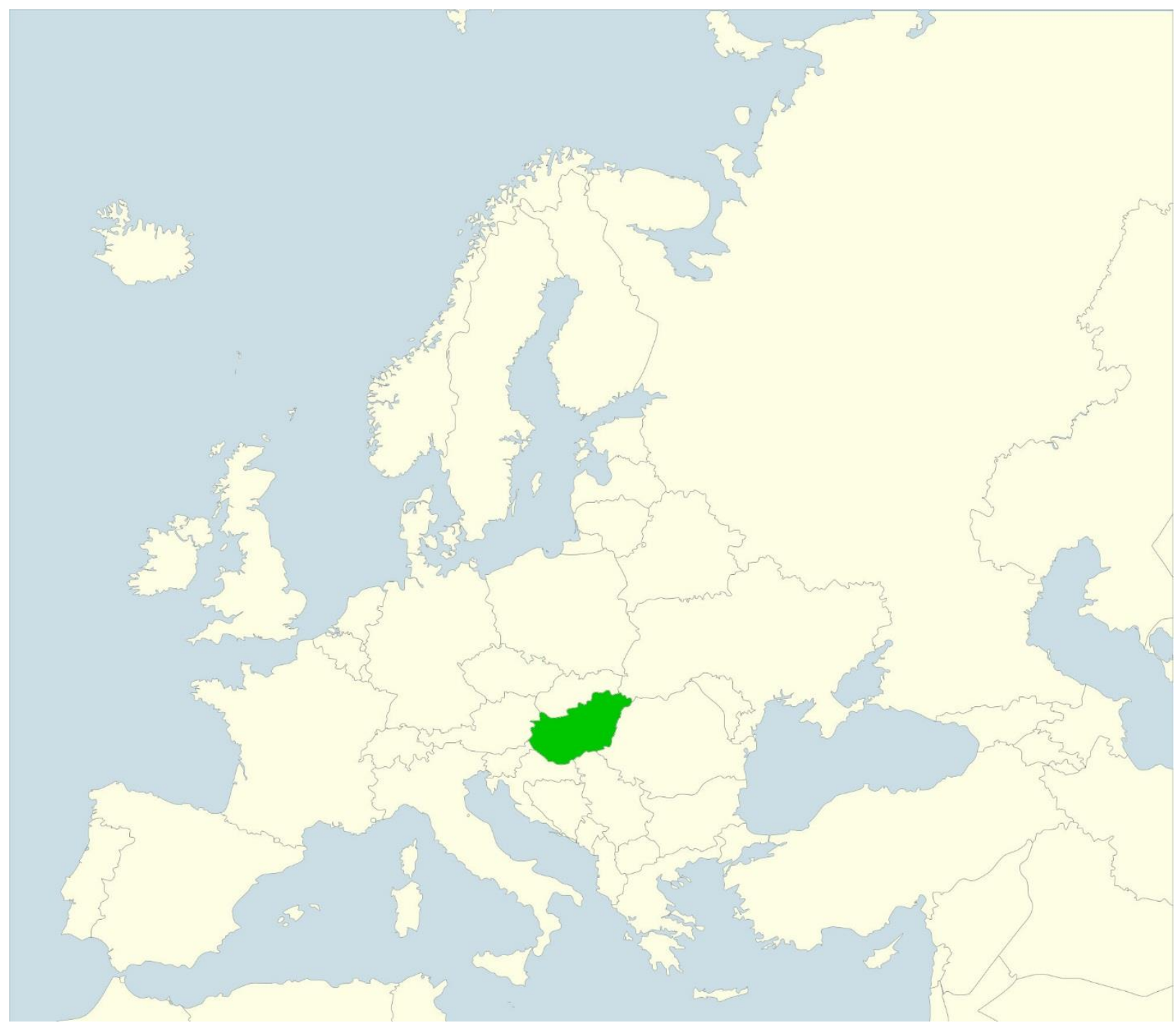

${ }^{1}$ Associate Professor Csaba Patkós, PhD, FeRSA, Eszterházy Károly University College, Institute of Geography and Environmental Sciences, 1 Eszterházy tér, H 3300 Eger, Hungary; Email: patkos.csaba@uni-eszterhazy.hu 


\begin{abstract}
LEADER local action groups (LAGs) have become an integral part of the European rural landscape. Our article examines how LEADER groups operate in Hungary by analysing their territorial, symbolic and institutional shape, and the established role of LAGs in Hungary. The results reveal an irregular territorial shape combined with uncertain symbolic form. The institutional constellation is significantly influenced by the size of the member municipalities. Action groups integrating smaller local authorities must involve more NGOs and enterprises to fulfil participatory regulations. Local bureaux are small and their functions are not differentiated according to the state of development. Although Hungarian LAGs, in a European comparison, have many levels of tasks their level of governance is relatively low.
\end{abstract}

Keywords: Rural development, LEADER approach, governance, institutionalisation

Összefoglalás: A LEADER helyi akciócsoportok az európai vidéki térségek integráns részévé váltak. Cikkünk azt vizsgálja, hogy a magyarországi LEADER programok során az akciócsoportok milyen területi, szimbolikus és intézményi jellegzetességeket mutattak, illetve milyen szerepköröket tudtak betölteni. Az eredmények azt mutatják, hogy az akciócsoportok területi és szimbolikus dimenziói általában instabilak és változékonyak. Az intézményi összetétel nagyban függ a résztvevő önkormányzatok méretétöl, hiszen ott ahol kisebbek a települések, a szabályok miatt több civil szervezetet és vállalkozást kell bevonni. A helyi irodák személyi állománya kis létszámú, feladatkörük pedig nem differenciálódik a különböző fejlettségü térségekben. Bár a magyar akciócsoportok - európai összehasonlításban széleskörü feladatrendszerért felelnek, a jó kormányzás csak alacsony szinten valósul meg.

Kulcsszavak: Vidékfejlesztés, LEADER-megközelítés, jó kormányzás, intézményesülés

\title{
1. Introduction
}

Rural life is a symbol of backwardness in Hungary. Consequently, development activities are inevitable for the socio-political actors involved (Kovács 2012). Since Hungary joined the EU in 2004, Community financial aid has become the decisive source of funding for rural development. Through allocative practices, different (centralised or partly de-centralised) institutions distribute huge amounts of money through a sometimes controversial application system. Fekete (2001) supposed a continuous fluctuation between centralised and de-centralised development approaches. The LEADER approach has tried to introduce a decentralised way of allocating fundsin Europe since the beginning of the 1990s. A bottom-up approach, local partnership in planning and implementation, as well as the vindication of local governance were the main distinctive characteristics of the initiative. In Central Europe, some scholars welcomed LEADER as a revolutionary method of catching up for backward rural regions (Kovách 2000). Unfortunately some experiences say that the de-centralised 'approach was unlikely to be a success in Hungary.

At the same time, in other Central European countries, scholars appear to complain about conflicts between LEADER theory and its implementation. The lack of autonomy and real partnership, the instability of the program framework, the lack of innovation, the overbureaucratised and unclear administrative circumstances make the life of local actors difficult (Svobodá 2015, Bedrac \& Cunder 2010, Kisiel \& Gierwiatowska 2013). A comparative study on the LEADER programmes of Central and Eastern European countries indicated the survival of former practices like favouritism and paternalism. Consequently, the lack of proper participation of local citizens and the prevalence of interventionist routines led by central administration is routine (Maurel 2008). Furmankiewicz and Macken-Walsh investigated the composition of Polish LEADER communities and recognised that government related actors are over-represented in 
them. According to their primary research, government actors in LAGs are often camouflaged as NGOs or enterprise representatives (Furmankiewicz \& Macken-Walsh 2016).

In the case of Hungary, after a short period of experimental programs financed by the national government (2001-2004), the mainstream LEADER+ program was initiated after the 2004 EU access. Although this was huge progress for a post-socialist society, the many negative experiences and disappointments made the actors dissatisfied. A common joke among LEADER participants is:

\section{"What's the difference between ÁVH ${ }^{2}$ and $M V H^{3}$ ?}

One capital..."

MVH was a key actor in the Hungarian rural development institutional system as part of the central state administration. One of its main responsibilities was the control of LEADER LAGs by making the final decision about the financial support of applicants. Actors in rural development, including LEADER stakeholders, often complained about the dirty tricks emanating from this organisation. It seemed to many people that $\mathrm{MVH}$ is interested in retaining EU subsidy money from beneficiaries and wanted directly to block LAGs. Redundant delays in financing and aimless administrative temporisations were frequent (Csurgó \& Kovách 2015).

In the new programming period (2014-2020), the national government of Hungary is aiming to re-organise the managing-authority system of rural development. MVH is going to be integrated into the structure of ministries and central LEADER management is supposed to work in a different way (Government Regulation No 1312/2016. VI. 13.).

The Hungarian National Rural Network has also compiled a set of recommendations about the directions of reform. Less bureaucracy is proposed; more power for LAGs is assured. Clearer spheres of action for every participating organisation should be embedded in the system. In addition, 'LAGS composed of more talented participants are also suggested by the Network (Finta et al. 2013).

Continuity and undisturbed operation of local communities might be added to this set of aims because the literature also states that experienced and autonomous LAGs can be more successful (Lukesch 2007, Fekete 2014).

\section{Research aims and methods}

Our article aims to review some features of the controversial LEADER program implementation in Hungary. Firstly, some information will be provided on the general traits of the Hungarian LEADER approach. Secondly, 'a brief outline of the theoretical framework will be provided. Finally, some preliminary results will be presented in four parts according to the four phases of the institutionalisation of regions. We are seeking answers to the following questions:

- Does the spatial appearance comply with the LEADER principles and European trends?

- To what extent can spatial and symbolic continuity be observed among Hungarian LAGs for different LEADER periods?

- Does the composition of action groups fit the EU directives? Do they reach the "critical mass" of being able to successfully influence the development of their areas? Is the size of administrative units big enough to support LAGs effectively?

- What level of governance is reached by institutionalised local action groups?

During our project, beyond the analysis of the relevant academic literature and the EU legal documents, we compiled a basic LEADER LAG database containing some relevant information (area, population, composition etc.) about each and every action group formed since the beginning of the program. Database creation is crucial as it will also be the basis of sampling. As our broader aim will be the investigation of the whole European LEADER program, the database contains each and every member state and it covers every LEADER period since

\footnotetext{
2 ÁVH (Államvédelmi Hatóság) was the State Security Authority in the Stalinist era (1950s).

${ }^{3} \mathrm{MVH}$ is the Agricultural and Rural Development Office (Mezőgazdasági és Vidékfejlesztési Hivatal).
} 
1991. It contains all existing or previously existing European LEADER action groups. The compilation of such a system is a difficult task as access to the data is limited. There are some online EU Observatory databases concerning different LEADER phases. For the most recent LEADER cycles, their information content is almost perfect. Unfortunately, for LEADER II, the information is seriously lacking. The missing data are mainly spatial and related to population. LEADER I was implemented before the Internet boom, consequently only printed material about action groups is available (Table 1). In the case of the Hungarian LAGs, the two later periods were considered.

Tab 1. Main sources of LEADER LAG database creation. Source: Author's table

\begin{tabular}{|l|l|}
\hline LEADER period & Source \\
\hline LEADER I & AEID 1994 \\
\hline LEADER II & http://ec.europa.eu/agriculture/rur/leader2/ \\
\hline LEADER + & http://leaderplus.ec.europa.eu/cpdb/public/lag/lagsearchfs.aspx \\
\hline LEADER 2007-2013 & $\begin{array}{l}\text { http://enrd.ec.europa.eu/enrd-static/leader/local-action-groups/en/local- } \\
\text { action-groups_en.html }\end{array}$ \\
\hline
\end{tabular}

The fourth stage of institutionalisation was analysed using a questionnaire sent to the Hungarian local action groups. Beyond general issues (position, education, age of the respondents), questions related to the institutionalisation of LAGs (spatial dimension, symbolic shape, institutional circumstances and identity) were asked. The majority of questions were compiled according to the work of Lukesch (2007) on the "forms of governance". There are nine thematic blocks, each containing 10 typical statements for different forms of governance that can help to place LAGs in a grade of governance. The questionnaires were sent to the LAG bureaus by email. The majority of answers came from either the presidents of the LAGs or the bureau managers.

\section{Institutionalisation: a possible theoretic model for LEADER local action groups}

Participatory development models are of great importance, and multi-level governance is a key factor in EU policy . Bottom-up initiatives create socially constructed local and regional spatial units through a multi-layered process, where communities and places frame each other through different (formal and informal) institutional practices, such as the implementation of territorial development strategies (Raagmaa 2015).

Gailing (2012) specified LEADER groups as "collaborative organisations" creating "socially constructed landscapes" just like touristic regions and biosphere reserves based on the theory of the institutionalisation of regions in the case of the Spreewald area. Gailing and Leibenaht (2015), in their theoretical article, emphasise the role of historical institutionalism in landscape-creation.

In a comparative study, Maurel (2016) paralleled some Czech and Hungarian LEADER action groups by identifying their main territorial, symbolic and institutional patterns as well as the characteristics of their programme implementation.

The LEADER approach, on the one hand, is a set of principles determined by the EU. On the other hand, its specific implementation is nationally and locally bounded. As Maurel states, the model is downloaded through several ways of governance (Maurel 2016). It can be said that the successful agency of local action groups is a multi-dimensional phenomenon.

LEADER local action groups can be studied as socio-spatial organisations. Accordingly, Paasi's theory about institutionalisation seems to be a suitable way to analyse them. Originally Paasi (1986) elaborated his system for regions, but we suppose it is useful as well for sub-regional units such as LAGs. As we will see, many authors have used this framework for the analysis of LEADER groups in different countries. Krámos (2015) used Paasi's whole four-phase theory to analyse the renewable energy harvesting LEADER action groups in Hungary.

According to this framework, a LAG can be studied in four dimensions. In the case of the territorial form, the size and the relation to other official territorial units (do they cross regional/county 
borders?) can be researched. LAGs are definitely sub-regional spatial beings. Their spatial appearance might be investigated through different aspects. Beyond the size (area and the number of integrated municipalities) and the range of local action groups, their territorial congruence with other spatial units (e.g. administrative ones) can be relevant (Salchner 2014). On the one hand, Maurel stresses the relevance of incorporating coherent areas to reach a sufficient critical mass of local assets to support local strategic goals. On the other hand, he reminds us of the European Community initiative to standardise the size of LAGs (Maurel 2016).

The symbolic shape is the second characteristic to be examined. Names, logos and other territorial symbols can make different territorial units vibrant. Additionally, identity is created by their frequent utilisation (Šifta \& Chromý 2017). Rural development activities can be more successful with a more established and stable identity because additional hidden local resources are more effectively mobilised through them. A recent article (Semian, Chromý \& Kučera 2016) analyses the LAGs of the Czech Republic using Paasi's doctrines as a frame. The authors concentrate on the symbolic formation of local LEADER communities. In their project, Kurka, Maier and Sedlacek (2007) examined the "Waldviertler Wohlviertel" LEADER action group, using a "regional identity index" based on Paasi's theory.

The third characteristics is a set of institutions working in the area. Beyond the purely legal status, other factors can be taken into consideration such as the composition of LAGs, that of the decision making bodies or the characteristics of working organisations. Though the proportion of private and public actors should be balanced in the composition of action groups, there are certain anomalies showing the overwhelming role of local politicians (Furmankiewicz \& Macken-Walsh 2016).

An action group consisting of just a few members, on the one hand, can be declared elitist (Thuesen 2009). However, a smaller LAG might be managed more easily and bottom-up development could be achieved. Local communities can be successful with a management unit that has a competent and experienced professional staff (Salchner 2014).

According to Brosei (2012), LAG management, on the one hand, should care about the animation of local stakeholders and the motivation of local actors, and, on the other hand, must implement development programs properly (including administrative and financial elaboration) (Figure 1). The former is to be more important in marginalised rural areas while the latter is more relevant in dynamic zones. In close interrelation with this, Brosei specified three different LEADER operation models in Europe (Figure 2).

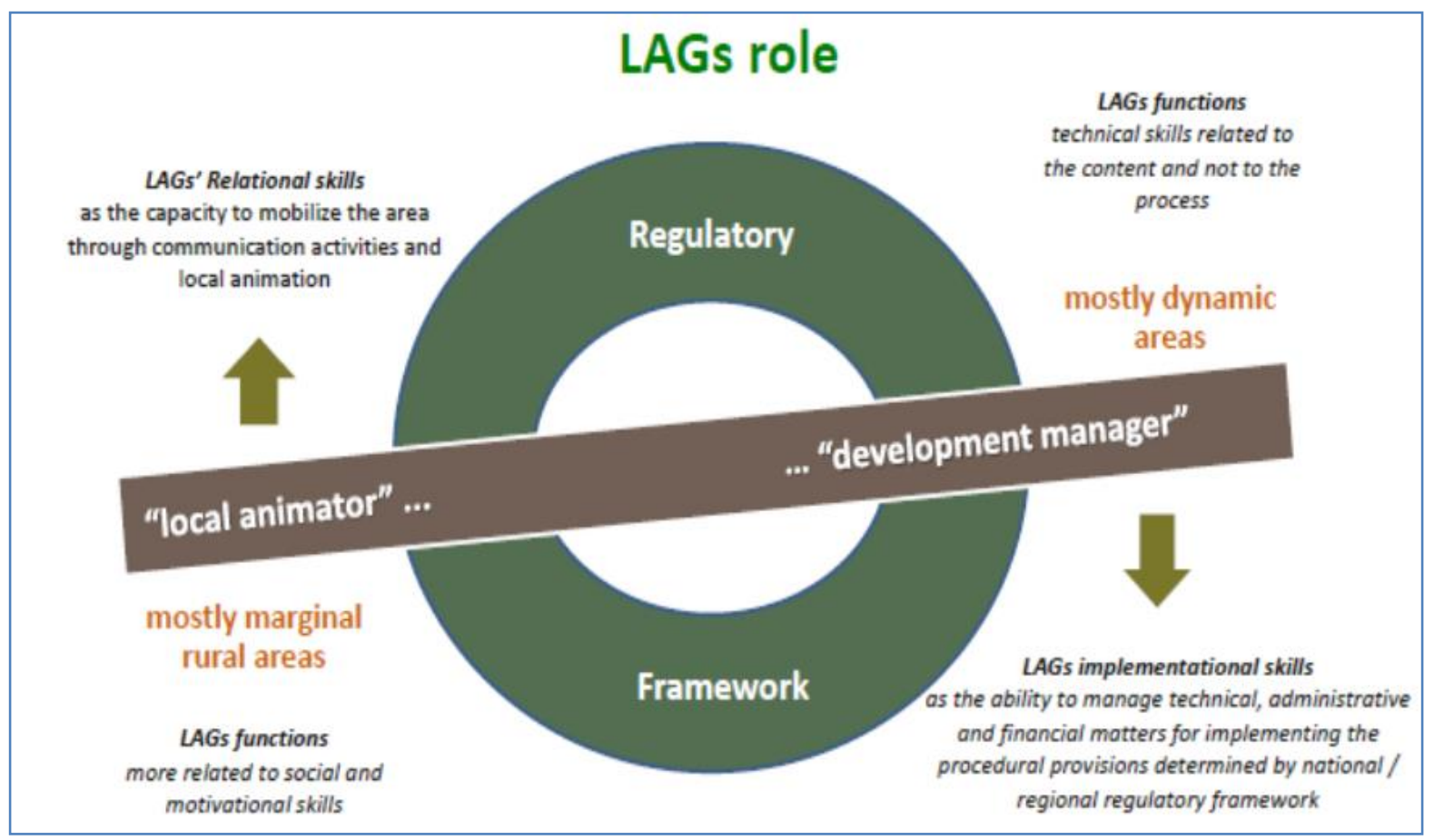

Fig 1. LAGs' different roles (Brosei 2012). 


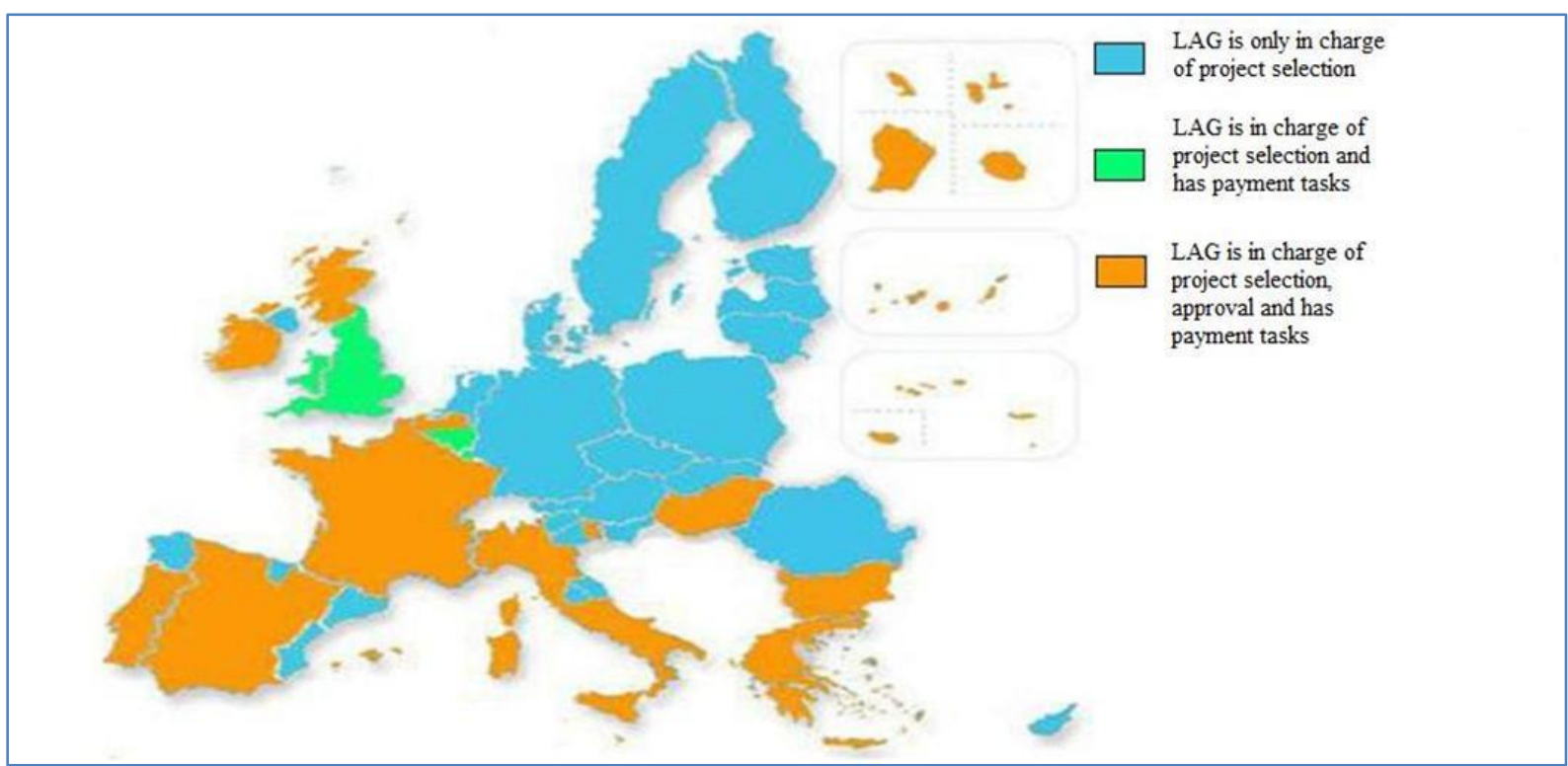

Fig 2. LAGs' operational models in Europe (Brosei 2011).

Finally, through social structuring, the established role of local and regional spatial units is created. Paasi emphasises the role of identity in this phase. He interprets it as a form of collective activity by individuals to support the spatial unit (Paasi 1991). According to Lukesch (2007), identity can make local inhabitants "more empowered" so it leads to more developed governance activities.

As the function of LAGs, beyond the spread of development sources, is the empowerment of local people and interest groups, the contribution of LEADER to the level of governance should be relevant. As governance itself is a rather contested concept, its measurement is complicated. Forms of governance questionnaires may help to find out whether LAGs are widely accepted entities in the local spatial constellation (Lukesch 2007).

\section{A short history of the Hungarian LEADER program}

Ever since the regime change'rural development has been part of the spatial/regional development system. Its real autonomous life started with the rise of the EU pre-accession agrarian aid (SAPARD) where a new EU-conforming institutional system had to be organised including at micro-regional spatial level (Kovács 2012). In 2001, in Hungary, bottom-up rural development planning processes took place in 192 micro-regions (Nemes 2005).

Before the EU access, there were also other experimental programmes, financed by either external (FAO) or national sources (e.g. foundations) aiming to motivate the bottom-up development processes of different micro regions (Tácsik 2009).

The first real LEADER program implementation began in 2001, financed from national sources but organised along the European principles and methods. Altogether fourteen local communities received finance to develop their integrated rural development plan and to implement their objectives. In total, 270 local small projects were given financial support in the program. This stage was a real success story as local communities joined the program with great enthusiasm. The real aim was achieved with the start of a learning process where rural actors could learn how European development methods can function in their own region (Krolopp et al. 2005).

The LEADER+ stage began after Hungary's 2004 EU accession. Firstly, training for members of the potential LEADER communities was established. A state-owned and centrally controlled organisation (Promei Public Company) was responsible for the training of future LAG members. After regionally de-centralised education events, 186 action group formations were started. According to central regulations, LAGs did not have to be incorporated into a legal entity, consequently casual consortiums were formed from municipalities, NGOs, enterprises and individuals. Central state administration, led by the Hungarian Ministry of Agriculture, 
implemented a two-round selection process. In the spring of 2006, 68 action groups were recognised and had the opportunity to implement their integrated rural development plan and allocate 90-100 million HUF to the areas (nationally 7 billion HUF). The total area of local development communities covered 29,000 sq. $\mathrm{km}$. (cc. one third of the country's area). Sixteen per cent of the population of Hungary was living in LEADER areas. The major part of the finance was used to support the ideas of NGOs, municipalities and enterprises. In total, 2,700 local development projects received support from LAGs (Bogár 2011). At the same time, the final decision on project selection was made at national level. Unfortunately, the whole implementation was characterised by administrative difficulties and frequent delays. ${ }^{4}$

The 2007-2013 cycle was Hungary's first full LEADER program. The central political intention aimed to involve as many settlements as possible into newly founded or previously existing but extended action groups. In contrast with the previous period, action groups had to become a kind of legal entity. ${ }^{5}$ Although LAGs had more responsibilities (e.g. they participated in the distribution of rural development resources belonging to Axis III) than before, decisions were subordinated to central administration. After the 2007 registration process, 96 local communities started to operate from 2008. In total, 3,020 villages and eligible towns joined the local action groups and 70 billion HUF was available for program implementation (Kiss 2016). During the operation, some of the LAGs were dissolved and re-organised because of operational issues. The implementation of the LEADER approach, up to this point, was declared ineffective as a way of contributing to the development of the rural areas concerned (Kovács \& Váradi 2013).

Currently, the 2014-2020 period is ongoing. At the end of 2015, 104 LAGs were given recognition by the central national rural development administration, integrating in total, 3,013 settlements. At the same time, so-called community-led local development (CLLD) initiatives were started in bigger cities. However, the financial background is different. While rural action groups will be paid (4.6\% of the full community support is provided for LEADER) from the Rural Development Operative Programme (VP), urban CLLDs are financed by the Spatial Development Operative Programme (TOP) (Lechner 2015).

\section{Results and discussion}

In this chapter, some of the preliminary results of the project concerning Hungary are presented.

Figure 3 depicts local action groups from all generations of the Hungarian LEADER process. Triangles represent the so-called "pilot-LEADER" cycle; squares show the LAGs of the LEADER+ and rhombi symbolise the 2007-2013 local communities. In the experimental era, action groups were small in a geographic and also in a demographic sense. Many of them functioned quite well as a bottom-up approach could prevail and grassroots were able to join in a micro-regional governance process (Ruszkai \& Kovács 2013). In the next period, although the size of some LAGs became gigantic, compared with the previous years' data, the extent of the majority of action groups remained moderate. The age of really big local communities started in 2007 when they became really huge in size and were more diversified (Table 2). The growth of deviation in area and population at odds with the mainstream EU tendency of standardising LAG size (Maurel 2008).

This evolution can be explained by the fact that the national government supported the enlargement of older action groups. On the one hand, it can be interpreted as a way of creating socio-economically more competitive spatial units. However, on the other hand, the management of these mega-LAGs frequently became a problem for local administrative staff. Sometimes even the collection of signatures for all the members proved to be a difficult task.

\footnotetext{
${ }^{4}$ While the final version of the tender call was published at the end of July giving only one month for final elaboration of documentation for applicants, the central decision on winner LAGs was made in the following March. Winners could start their resource distribution activities only after the parliamentary elections (June 2006).

${ }^{5}$ At first, LAGs took the shape of different kinds of legal entities (foundations, associations, societies, non-profit Ltds. etc.) but, from 2012, according to national law, each and every local community had to be transformed into an association.
} 


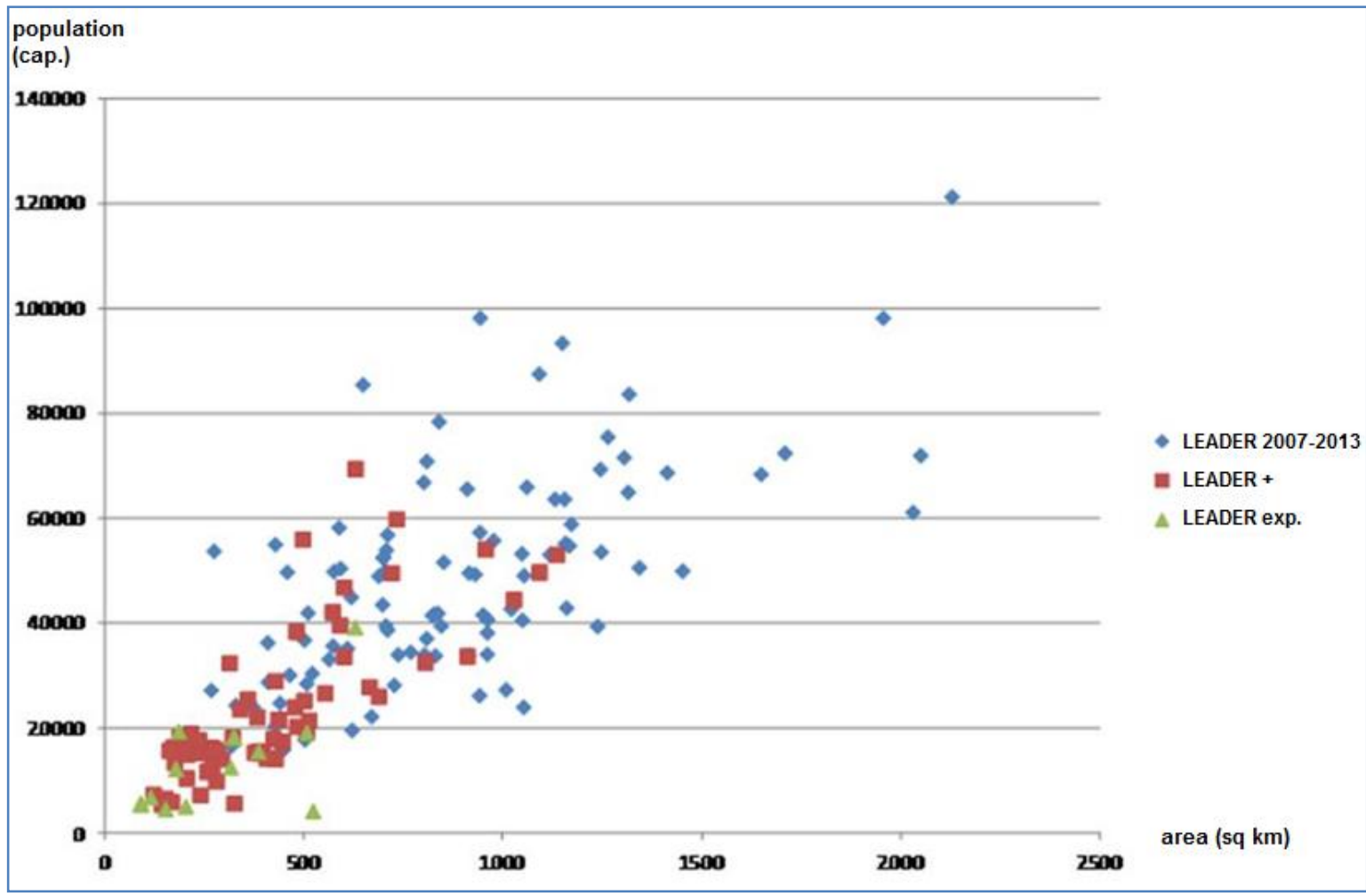

Fig 3. The spatial and demographic diversity of three generations of LAGs in Hungary. Source: Author's diagram

The situation is even more complicated when the territorial (dis)continuity of action groups is taken into account. In the transition between the first and second LEADER phases, many successful LAGs were dissolved (partly because of political reasons). The majority of LEADER+ groups were new-born and thus unable to follow up a continuous socio-economic development program. The situation became really serious in the least developed North Hungarian Region where none of the former experimental action groups were able to be active after 2006 (Figure 4).

Pilot LEADER action groups were formed to train local actors in community-led local development. There were many successful local initiations which were unable to follow through with their activities in the LEADER+ stage. This lack of continuity (for at least 2 years) caused stagnation in the development of local rural partnerships.

Tab 2. Basic statistics of the first three Hungarian LEADER LAG generations. Source: Author's table

\begin{tabular}{|l|l|l|l|}
\hline Area & LEADER Exp. & LEADER + & LEADER 2007-2013 \\
\hline Mean & 285.2 & 417.3 & 885.3 \\
\hline Median & 257.5 & 377.5 & 831.5 \\
\hline SD & 173 & 237.2 & 394.6 \\
\hline Population & \multicolumn{3}{|l|}{} \\
\hline Mean & 13372 & 23564 & 48880 \\
\hline Median & 12430 & 17981 & 49072 \\
\hline SD & 9550 & 14521 & 20064 \\
\hline Settlements & \multicolumn{3}{|l}{} \\
\hline Mean & 13 & 13.57 & 31.5 \\
\hline Median & 9.5 & 11 & 26.5 \\
\hline SD & 8.59 & 7.75 & 19.1 \\
\hline
\end{tabular}




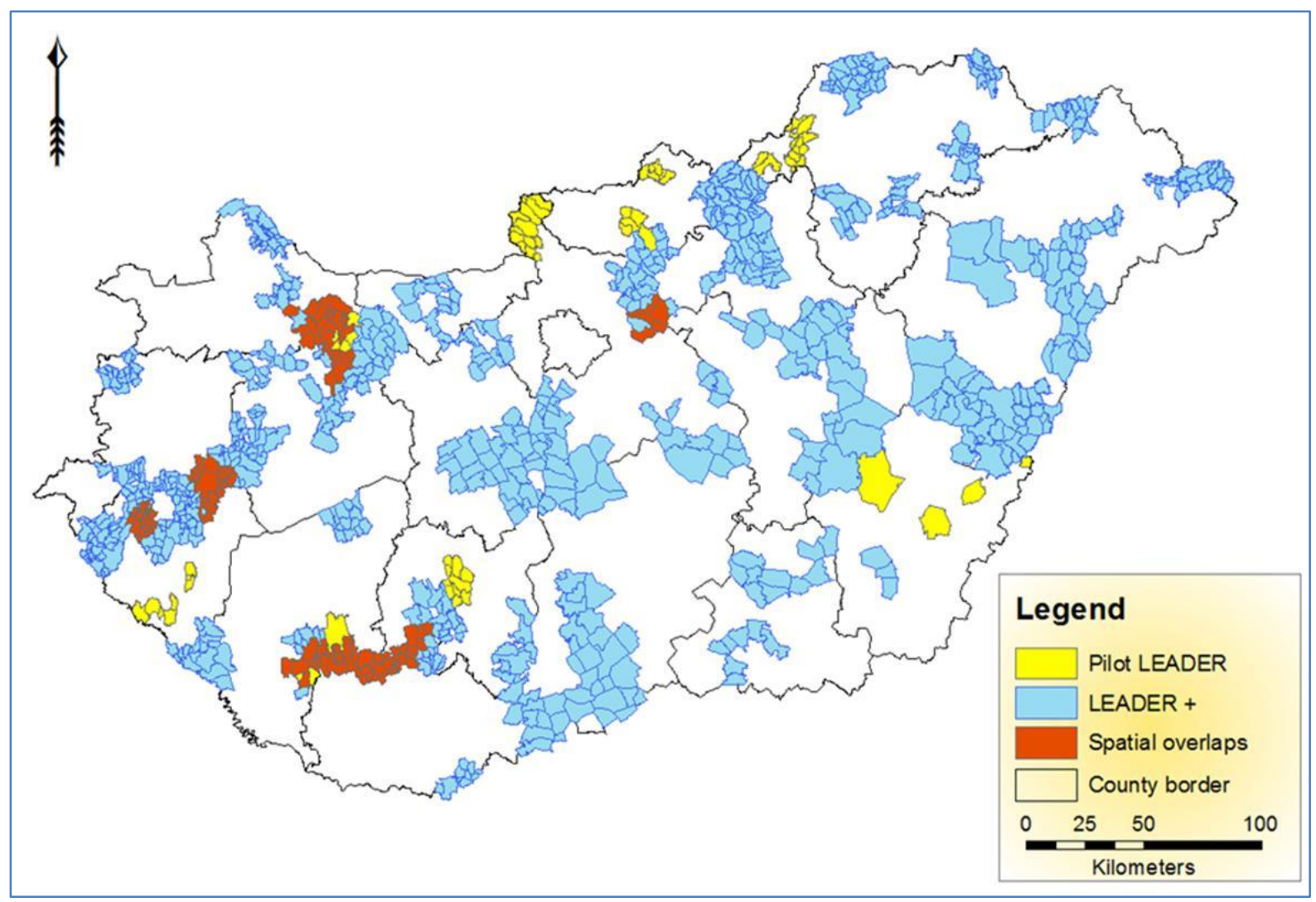

Fig 4. Territorial (dis)continuity of Hungarian LAGs (2004-2006). Source: Author's diagram

From the next map (Figure 5), one might conclude that the LAGs of the 2007-2013 period spread to almost all rural areas. According to our map, the "spatial overlap" means groups of settlements of the remaining action group members form the LEADER+ era. About two-thirds of the member villages were newcomers. Consequently, inexperienced masses of municipalities, NGOs and enterprises had to be integrated into pre-existing (but territorially expanded) or newly formed local communities. Action groups were motivated to involve as many actors as possible since the amount of subsidy mostly depended on the size. ${ }^{6}$ The only exception from this mass increase was the rim of the Budapest agglomeration where some villages were excluded from the eligible settlement category.

In the case of symbolic shape, the main factor to be investigated is the very name of the action group. Ideally, the local community's opinion and traditions should be mirrored by its name. Thus, the stability of names refers to more mature and deeply rooted LAGs with a strong identity. In such circumstances, processes of future creation (planning), governance and the distribution of development sources are smarter and smoother.

In the realm of symbols, the stability of local community names was observed. From 68 existing LEADER+ LAGs, only 13 retained their former names. In the case of other symbols (logos were examined as the most frequently used), this ratio was even worse. In these circumstances, one cannot expect a strong LEADER-related micro-regional identity (Figure 6).

\footnotetext{
${ }^{6}$ Some LAG staff members state that telephone books and yellow pages were used to invite as many NGOs and enterprises as possible into the community to maximize the size of membership.
} 


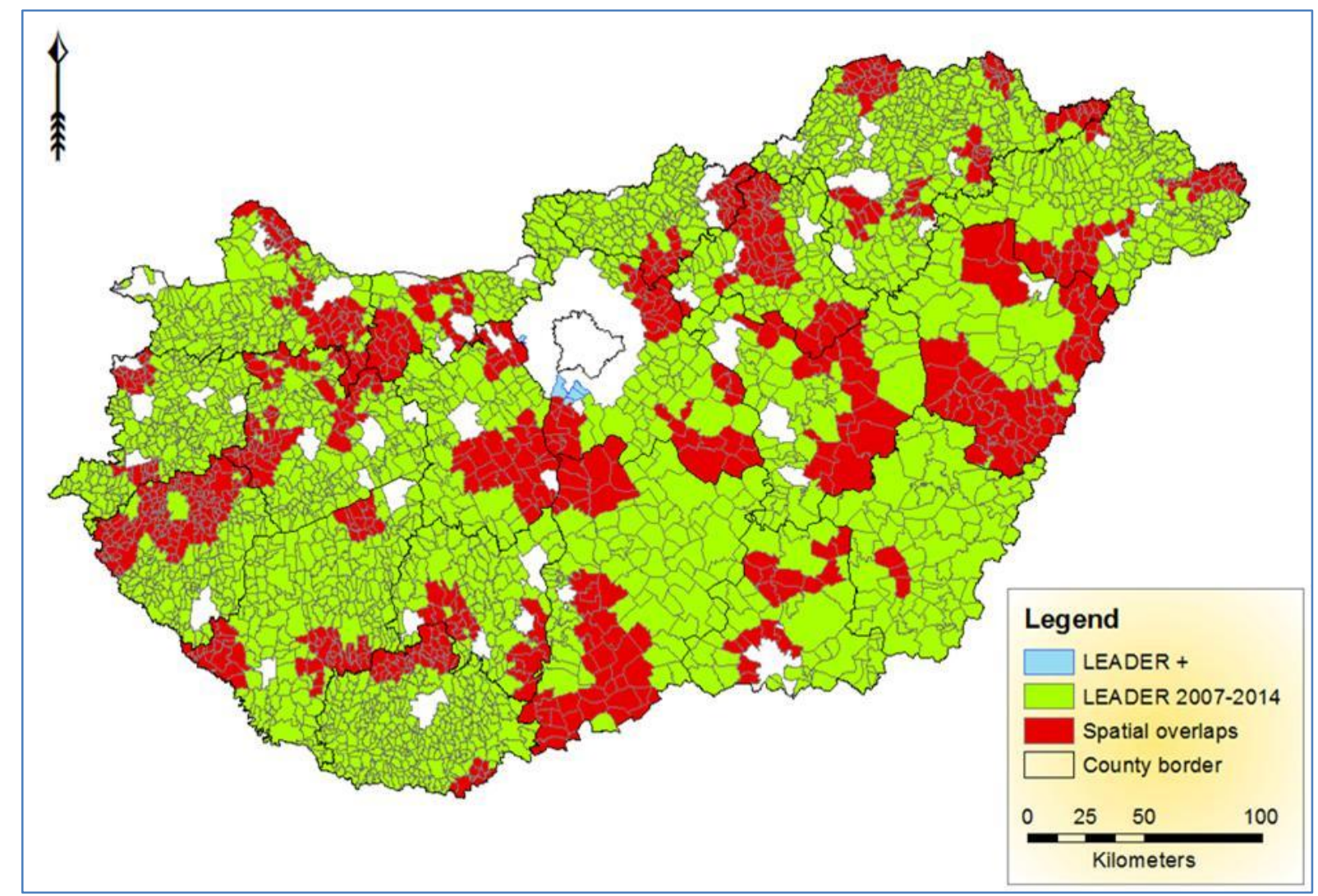

Fig 5. Territorial expansion of LEADER in Hungary (2007). Source: Author's diagram

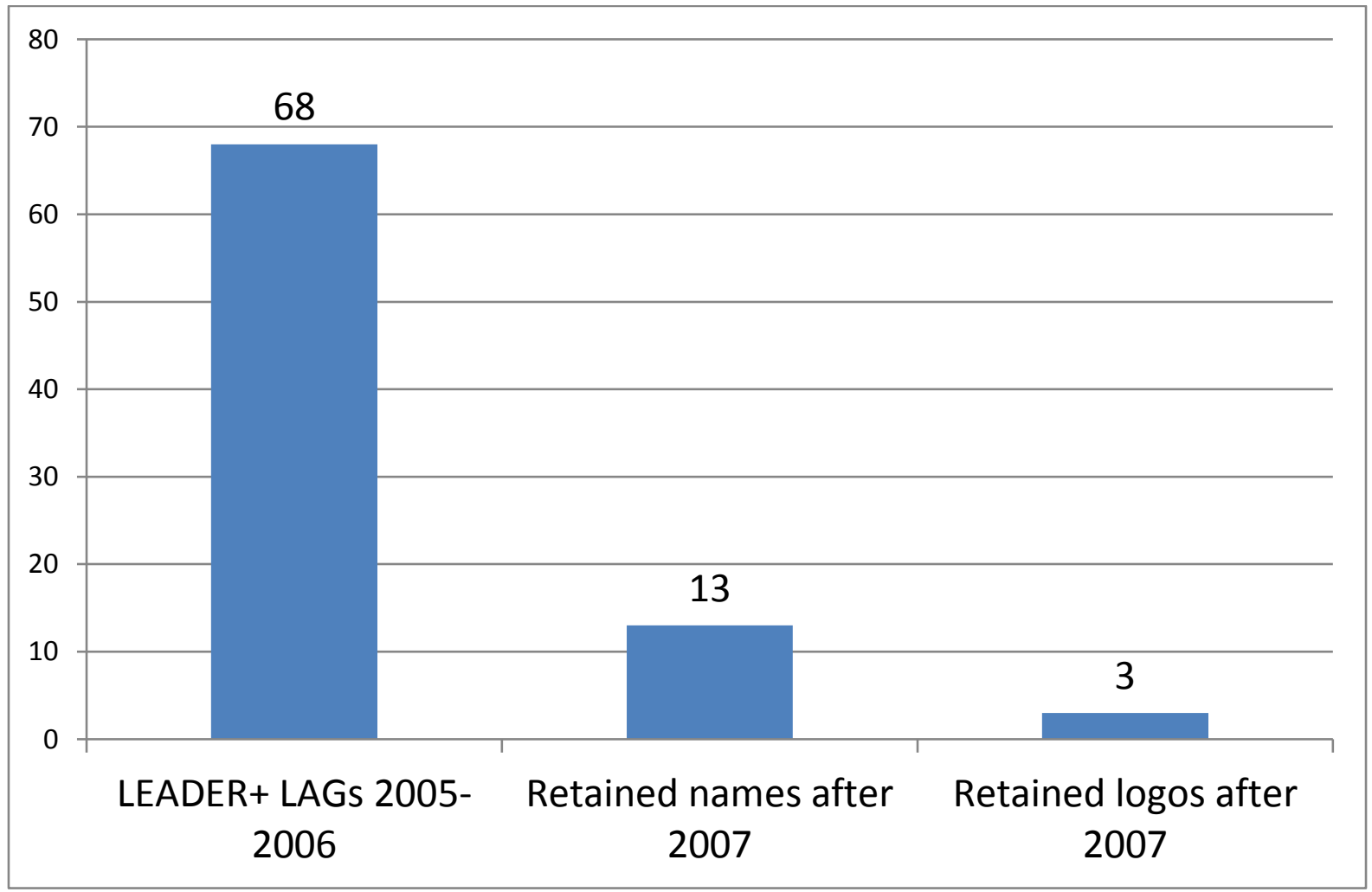

Fig 6. Symbolic stability of Hungarian LAGs (2005-2007). Source: Author's diagram 
The action groups possessing the three most persistent LAGs are "Gerje-sztök" from the Central Hungarian Region, "Kertészek Földje" from the South Great Plain Region and "Dél Baranya Határmenti Települések Egyesülete" from the South Transdanubian Region. Their stability may be model for future development (Figure 7).

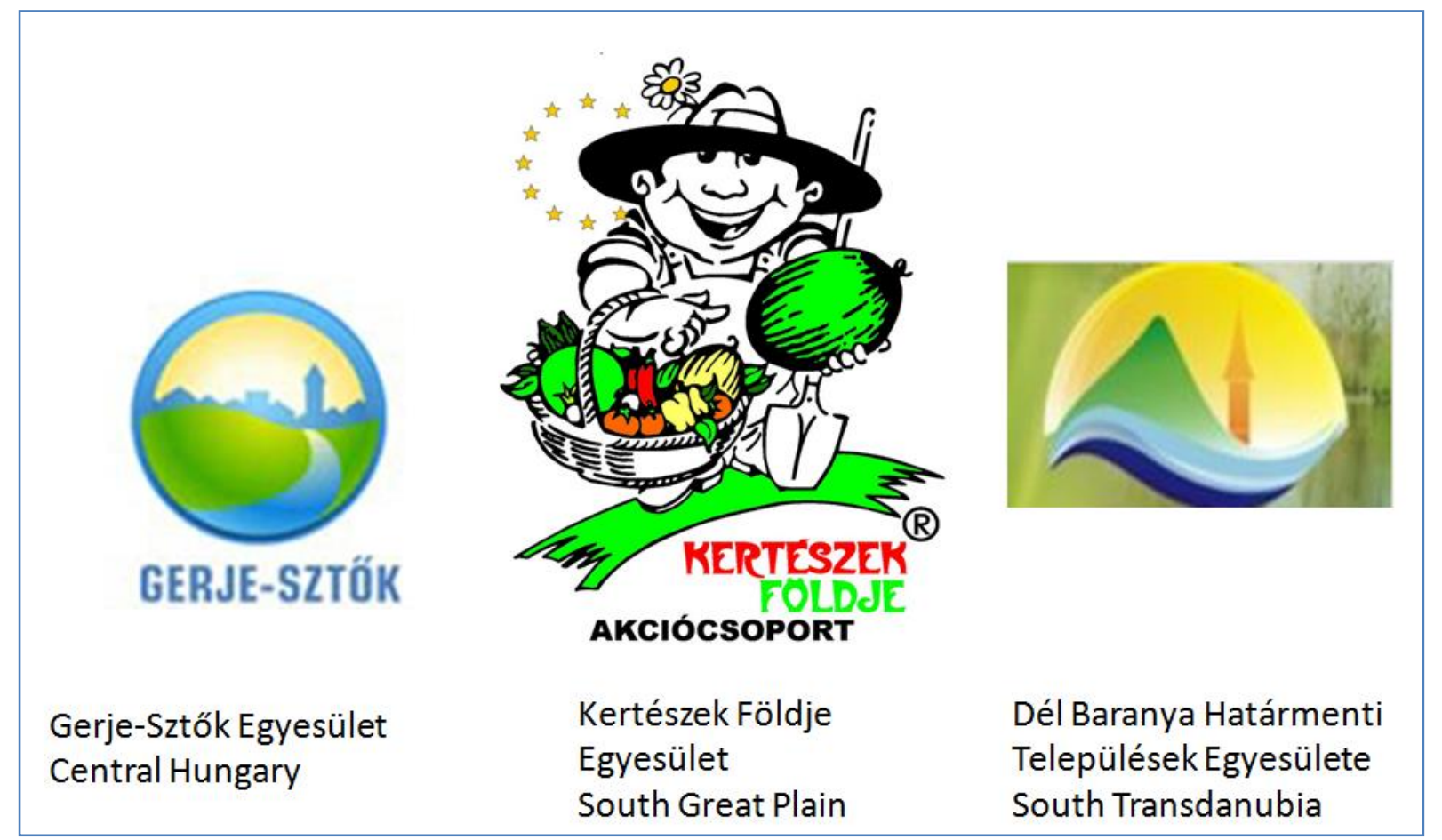

Fig 7. The three most durable symbols of the Hungarian LEADER landscape. Source: Author's diagram

The composition of LAGs was studied in relation to their institutional components. For each and every LAG, the number of institutions, NGOs and enterprises involved was retrieved from the text of the integrated development strategies. Of course this value fluctuates, thus in general the 2013 situation was tried to be recorded. In cases where of this information was missing, the former versions of development plans were used. The size of working organisations (local agencies) was also investigated according to an official document compiled by the Hungarian Ministry of Agriculture (ÚMVP 2013). In some cases, the website of the given action group was also checked for relevant information. Of course, other interesting factors, e.g., the composition of local decision-making bodies, the constitution of local development bureaus and the experiences of staff could be included in future analysis.

According to our research, an average Hungarian LAG consists of about 90 members, the ratio of municipalities and the civil sector is about one-third each, while the profit sector makes up $25 \%$ (Table 3). The "other" category represents mainly individuals or public bodies. From the map (Figure 8), we may differentiate LAGs with high and low membership. The former category is typical in North Hungary and in the South and West Transdanubian Regions (mainly in correlation with the areas having many small villages) while the latter can be found in the Southern Great Plain area. 


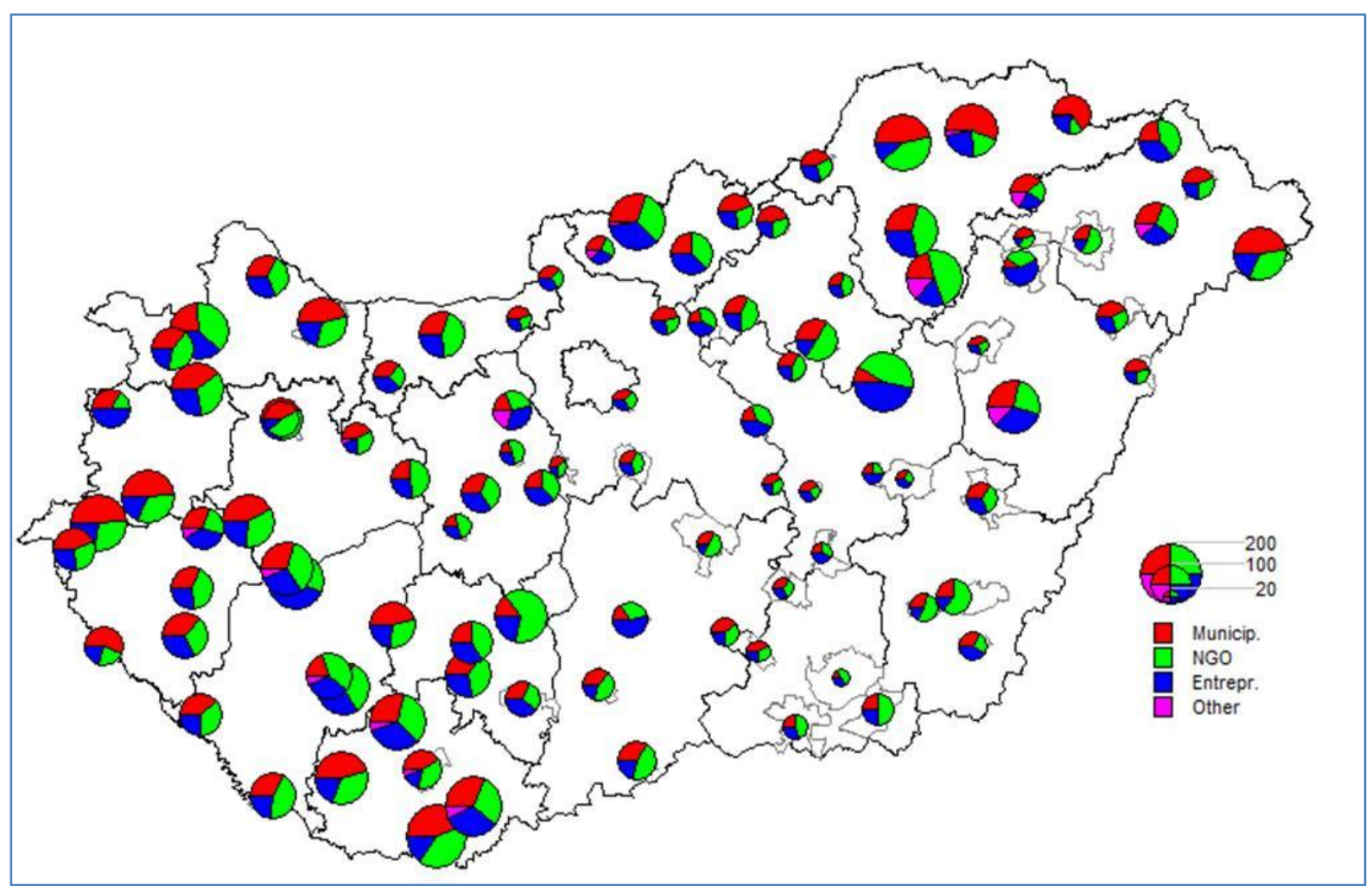

Fig 8. The map of the membership arrangement of Hungarian LAGs (2013). Source: Author's diagram

Tab 3. The composition of different Hungarian LAGs (2013). Source: Author's table

\begin{tabular}{|l|r|r|r|r|r|}
\hline & \multicolumn{1}{|c|}{ Municip. } & \multicolumn{1}{c|}{ NGO } & Enterpr. & \multicolumn{1}{c|}{ Other } & \multicolumn{1}{c|}{ Total } \\
\hline Max. & 88 & 90 & 81 & 24 & 195 \\
\hline Min. & 4 & 7 & 6 & 0 & 23 \\
\hline Mean & 31,5 & 31,7 & 25,6 & 1,9 & 90,7 \\
\hline
\end{tabular}

In addition to analysing membership, the sizes of local bureaus were also examined. While an average Hungarian LAG has a working agency comprising five people, the maximum value is 14 (in the case of the Bükk-MAK LAG, where post LEADER many different projects are implemented by the community). The smallest red points on the map mean the "secondary" local bureaus of the LAG. These are useful in bringing the governance process closer to the people. These action groups can be declared to be "de-centralised" (Figure 9).

An instructive issue can be the quantification of the ratio of LAG members and the headcount of administrative staff in them. Basically, a bigger LAG would be expected to have larger agencies. In the map, this ratio is illustrated, where red colours mean the smallest values, while green areas can be declared less favourable as one official must manage a huge number of members. Geographically, some action groups of the Great Hungarian Plain are in the most favourable situation. The worst rate is found in regions with many small villages. Some of them (in the South Transdanubian and North Hungarian regions) also happen to be the least developed microregions (Figure 10).

The fourth phase of institutionalisation concerns the evolution of the established role of the spatial unit. 


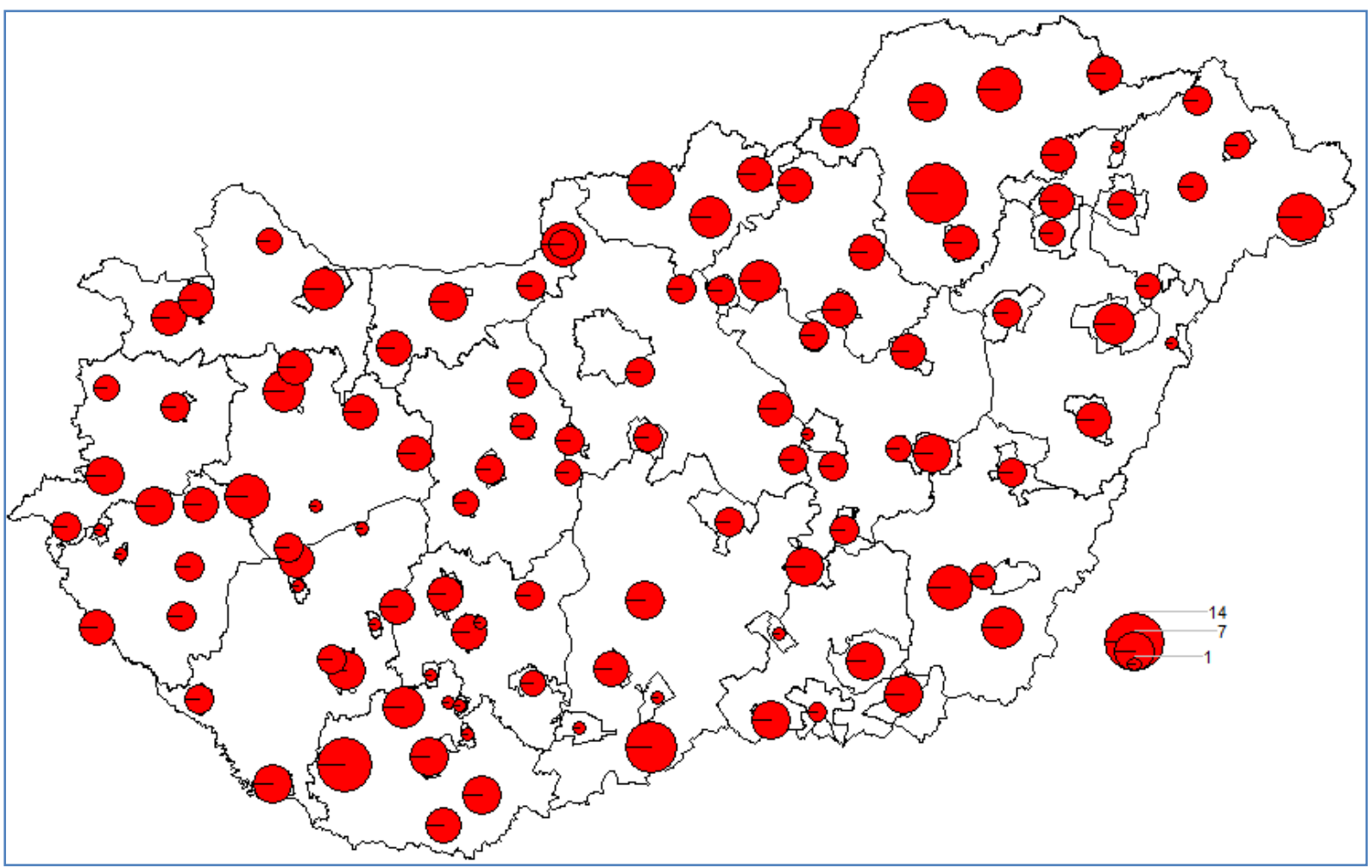

Fig 9. Size of administrative organisations of LAGs (2013). Source: Author's diagram

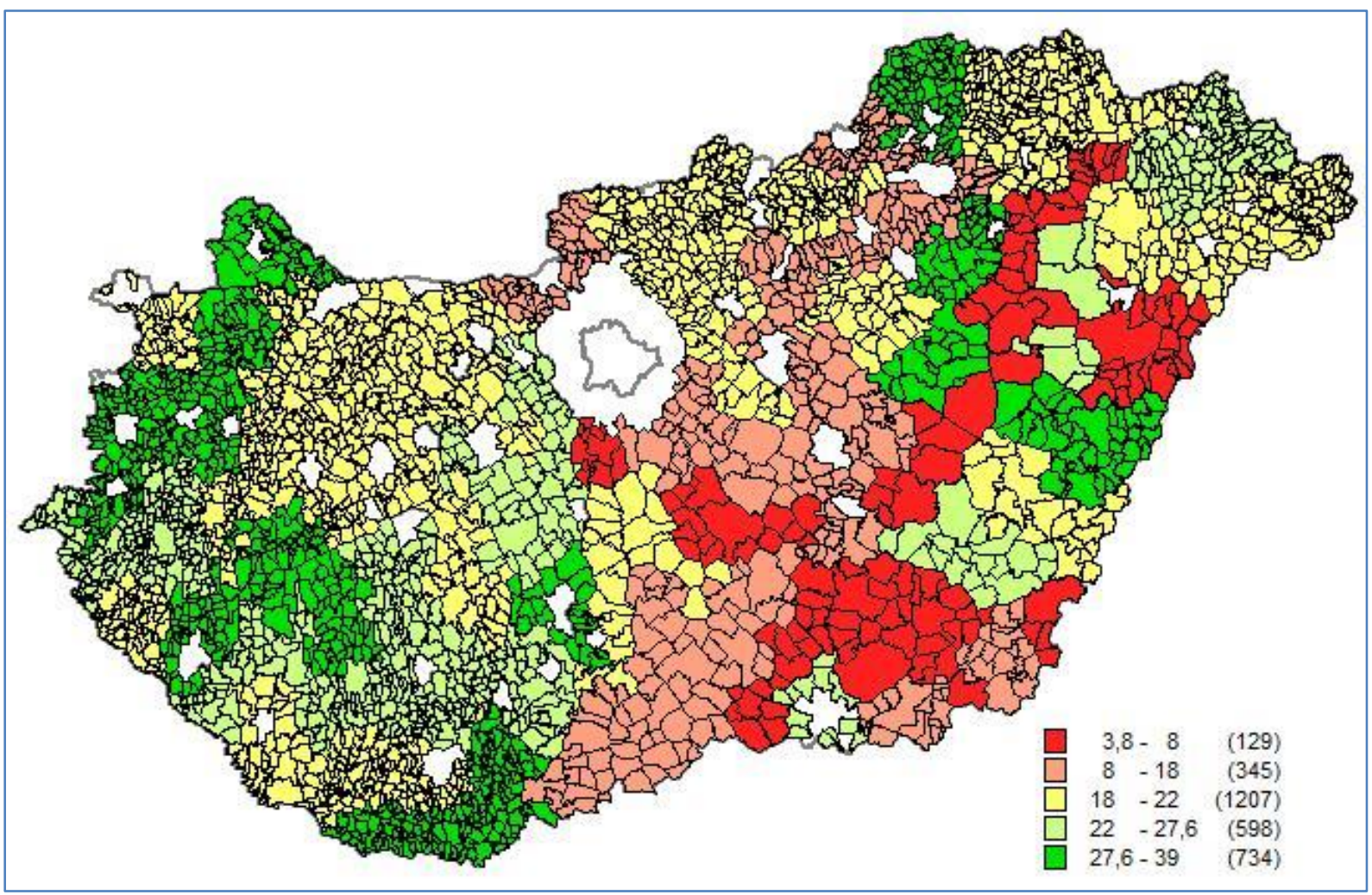

Fig 10. Number of LAG members per staff members (2013). Source: Author's diagram

Hungarian local communities belong to the third group (of the new member states, only Bulgaria and Hungary follow this model) consequently - in spite of their newness, they are responsible for a complex branch of administrative activities. Maybe a more sophisticated distribution of tasks and responsibilities between LAGs and central administration could make it possible for local level to foster animation activities, thus enabling more successful rural development in Hungary. 
The established roles may be viewed through the lens of governance. ${ }^{7}$ LAGs should operate as focal points for power-sharing, making possible the participation of different local stakeholders in planning, decision-making and the implementation of a common vision of the future. Lukesch (2007 created a so-called "forms of governance" (FOG) test in order to classify LEADER LAGs according to their level of prevailing local partnership processes. He argues for the emergence of governance as an onward process moving towards more developed phases (Table 4).

His "governance questionnaire" was sent by email to every existing Hungarian LAG in 2015. At first, there was only a limited number of responses, phone-calls had to be made to motivate LAGs. In the end, 28 out of 96 answered so the response rate was nearly $30 \%$.

Tab 4. Different levels of governance in case of LEADER LAGs. Source: Lukesch 2007

\begin{tabular}{|c|c|c|c|}
\hline Level & Keyword & Forms of governance & Main LEADER principle \\
\hline 1. & Survival & Sustenance & No LEADER pattern \\
\hline 2. & Identity & Allegiance & Area-based approach \\
\hline 3. & Power & Charisma & Bottom-up approach \\
\hline 4. & Legitimacy & Planning & Partnership approach \\
\hline 5. & Achievement & Competition & Multi-sector integration, innovation \\
\hline 6. & Equality & Conciliation & Bottom-up and partnership approach \\
\hline 7. & Uniqueness & Strategic vision & $\begin{array}{l}\text { Multi-sector integration, networking } \\
\text { and co-operation }\end{array}$ \\
\hline 8. & Sustainability & Shared responsibility & $\begin{array}{l}\text { Networking and co-operation, } \\
\text { decentralised management and } \\
\text { financing }\end{array}$ \\
\hline
\end{tabular}

Hungarian action groups can be stated to be at the beginning of the governance octave. Even the first stage (survival) has appeared in the answers. "Identity" and "power" were the two main principles dominating participants' points of view. It means, on the one hand, that common identities are key forces of local development, and, on the other hand, that local people are able to make their voices heard. Local opinion and will is usually amplified by local "strongmen" (Figure 11).

Uniqueness and achievement are two other themes relevant for Hungarian action groups. The former means the existence of a coherent strategic vision based on the unique strengths of the group. It is possible that extensive planning processes helped to support this dimension of LAGs. Achievement refers to the relevance of different economic actors being integrated into local alliances.

\footnotetext{
${ }^{7}$ Governance can be interpreted as a way of orienting, steering and coordinating the functions occurring in a region, community or institution (Kull 2014).
} 


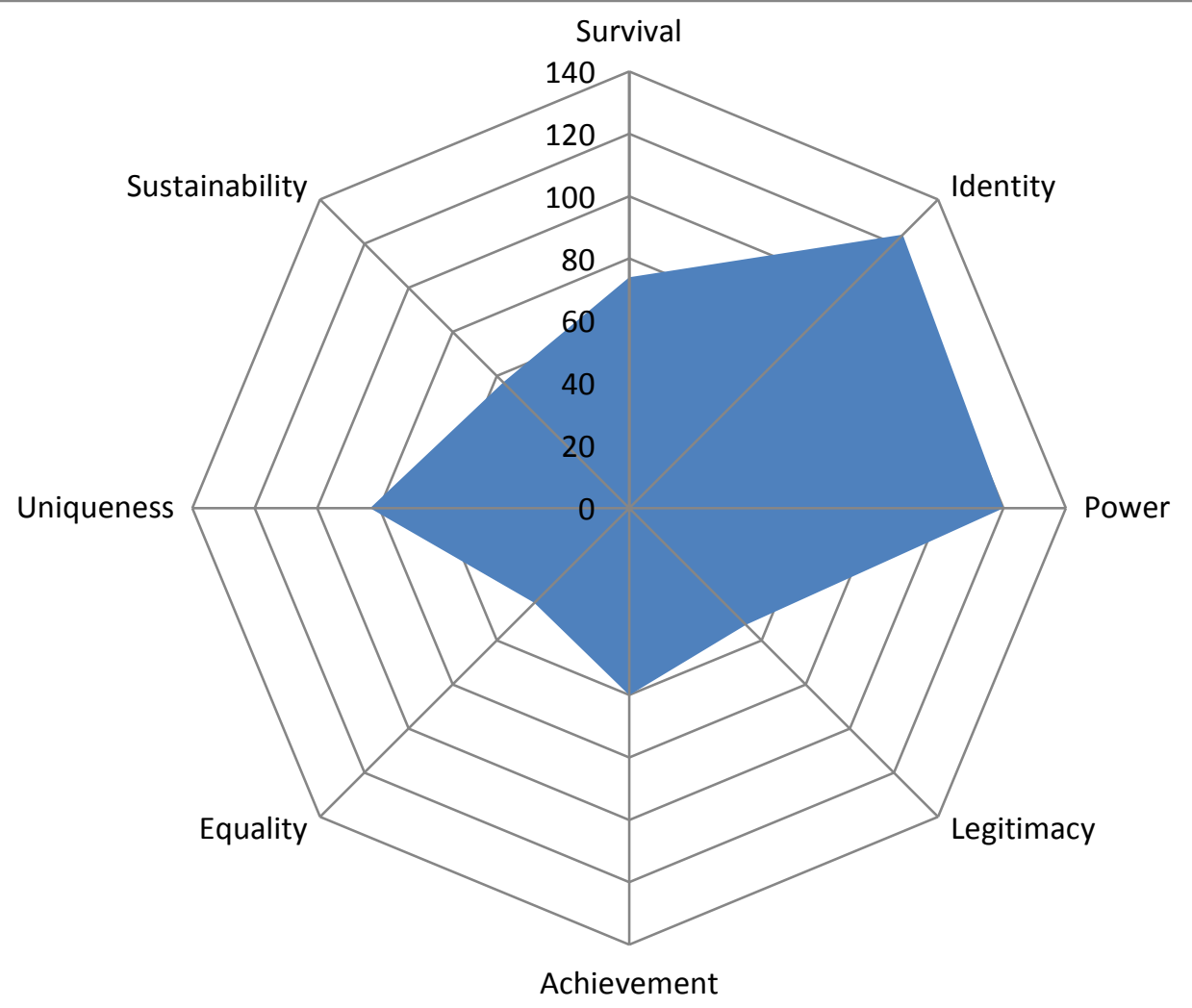

Fig 11. Dominant forms of governance in the case of responding Hungarian LAGs. Source: Author's diagram

\section{Conclusions}

The theory of institutionalisation is a viable academic framework for studying LEADER action groups. It integrates spatial, symbolic and institutional dimensions. In addition, the issues of territorial identity and governance can also be examined.

Surveying the history of the Hungarian LEADER program, we may state that, on the one hand, frequent organisational changes are present. On the other hand, ideally, many problems concerning multi-layered administrative and facilitative tasks should be solved.

Our research examined the four dimensions of three generations of Hungarian LEADER local action groups. Their spatial form can be declared to be impermanent as territorial changes in different cycles were significant. In general, LAGs became bigger in size and more variable. This growth occurred mainly because of government involvement. Therefore, the expansion of the components can hardly be seen as a positive development.

The symbolic shape is similarly unsteady with altering names and logos. Unfortunately spatial and symbolic discontinuity is frequent.

The number of LAG members is varied, but, in general, the institutional form is dominated by public actors and NGOs, while individuals and enterprises are relatively under-represented. The size of membership mainly depends on the size/number of municipalities. Local bureaus are relatively small, in keeping with the European trend. Their headcount does not correlate either with the number of LAG members or with the development level of certain micro regions.

From the established role point of view, the ability of action groups to co-ordinate local forces and channel them into development programmes through governance is at a low level. At this stage of governance, the evolution of identity creation is a main issue and the role of local prominence is crucial.

Perhaps after the realisation of the 2014-2020 cycle, hopefully with less bureaucracy, more stable spatial and institutional structures, more organic action groups could evolve reaching higher peaks of governance. 
The extension of the research to other European states could allow us to set up a system making international comparisons possible.

\section{Acknowledgements}

The author would like to thank Zsuzsa Piskóti-Kovács and Sándor Molják for their generous guidance on GIS-based map-making. The research on which recent article is based was supported by the Bolyai Research Scholarship of the Hungarian Academy of Sciences (BO/00542/13/10).

\section{Academic references}

[1] Bedrac, M. \& Cunder, T. (2010). "Leader" approach and local development strategies in Slovenia. In Fieldsend, A. ed. Rural Areas and Development (pp. 245-256). European Rural Development Network, Debrecen.

[2] Bogár, E. (2011). The LEADER program in Hungary and in Europe. Journal of Central European Agriculture, 12(3), 486-497. DOI: 10.5513/JCEA01/12.3.945.

[3] Csurgó, B. \& Kovách, I. (2015). The LEADER Programme in Hungary - Bottom-up Development with top-down control? In Granberg, L., Andersson, K. \& Kovách, I., eds., Evaluating the European approach to rural development (pp 53-78). Farnham: Ashgate.

[4] Finta, I. et al. (2013). LEADER 2014-2020. Javaslatok a felkészüléshez. Budapest: Institute of Economics, Centre for Economic and Regional Studies of the Hungarian Academy of Sciences.

[5] Furmaniewicz, M. \& Macken-Walsh, Á. (2016). Government within governance? Polish rural development partnerships through the lens of functional representation. Journal of Rural Studies 46, 12-22. DOI: 10.1016/j.jrurstud.2016.05.004.

[6] Gailing, L. (2012). Dimensions of the social construction of landscapes - Perspectives of new institutionalism. Proceedings of the Latvian Academy of Sciences - Section A: Humanities and Social Sciences. 66, 195-205.

[7] Gailing, L. \& Leibenaht, M. (2015). The social construction of landscapes: two theoretical lenses and their empirical applications. Landscape Research 40(2), 123-138. DOI: $10 . \overline{1080} / 0 \overline{1426397.2013 .775233 .}$

[8] Fekete, G. É. (2001). Együtt - de hogyan? Innovációk a kistérségi fejlesztésekben. MiskolcPécs: Institute for Regional Studies, Hungarian Academy of Sciences.

[9] Kisiel, R. \& Gierwiatowska, M. (2013). Functioning of the Polish LAG in the context of the LEADER initiative. Acta Scientiarum Polonorum Oeconomia 12(3), 39-50.

[10] Kiss, M. (2016). Helyi termék mint továbblépés? A helyitermék-előállítás szerepe és típusai a hátrányos helyzetü térségekben. Erdélyi Társadalom 14(1), 9-30.

[11] Kovách, I. (2000). LEADER, a new social order, and the Central and East-European Countries. Sociologia Ruralis 40(2), 181-190. DOI: 10.1111/1467-9523.00140.

[12] Kovács, K. \& Váradi, M., eds. (2013). Hátrányban vidéken. Budapest: Argumentum.

[13] Kovács, T. (2012). Vidékfejlesztési politika. Budapest: Dialóg Campus.

[14] Krámos, D. (2015). The topography of possible Hungarian renewable energy regions and cities: a possible interpretation based on three models. International Journal of Regional Development 2(1), 1-16. DOI: 10.5296/ijrd.v2i1.7022.

[15] Krolopp, A., Marticsek, J., Petri, M., Szuda, Z. \& Francia, R. (2005). "Egy európai eszme és hazai megvalósítása" LEADER - Közösségi kezdeményezés a vidék gazdasági fejlesztése érdekében. Budapest: CEEWEB. 
[16] Kull, M. (2014). European integration and rural development: actors, institutions and power. Farnham: Ashgate.

[17] Kurka, B., Maier, G. \& Sedlacek, S. (2007). Breaking the vicious cycle in peripheral rural regions: the case of "Waldviertler Wohlviertel" in Austria [Discussion Papers], Vienna University of Economics and Business.

[18] Lukesch, R. (2007). The LAG-Handbook. A guide through the stunning world of local action groups. Brussel: LEADER+ Observatory Contact Point.

[19] Maurel, M. (2008). Local development stakeholders and the European model: learning the LEADER approach in the new member states. Sociologický časopis / Czech Sociological Review 44(3), 511-529.

[20] Maurel, M. (2016). Building local development on territorial identity: lessons from implementing the LEADER public action model in Central Europe. In Regions in Europe. Administrative structures and territorial identity issues (not paged), Paris: L'Harmettan.

[21] Paasi, A. (1986). The institutionalisation of regions: a theoretical framework for understanding the emergence of regions and the constitution of regional identity. Fennia 164(1), 105-146. DOI: 10.11143/9052.

[22] Paasi, A. (1991). Deconstructing regions: notes on the scales of spatial life, Environment and Planning A 23, 239-256. DOI: 10.1068/a230239.

[23] Paasi, A. (1996). Territories, boundaries and consciousness: the changing geographies of the Finnish-Russian Border. Chichester: John Wiley \& Sons Ltd.

[24] Raagmaa, G. (2015). Territorial governance and core-periphery relations: the implications of European Policy concepts for Central and Eastern Europe. In: Lang, T., Henn, S., Sgibnev, W. \& Ehrlich, K., eds., Understanding geographies of polarization and peripheralization. New geographies of Europe (pp. 287-308). London: Palgrave Macmillan.

[25] Ruszkai, Cs. \&. Kovács, T. (2013). The Community Initiative LEADER I and the implementation and results of the Hungarian Pilot LEADER programme in rural development. Bulletin of Geography. Socio-economic Series 19, 87-97. DOI: 10.2478/bog2013-0006.

[26] Salchner, G. (2014). Setting up effective management in rural development. In Keszthelyi, A., ed., Proceedings of FIKUSZ 2014 (pp. 261-272). Budapest: Óbuda University.

[27] Semian, M., Chromý, P. \& Kučera, Z. (2016). Name as a regional brand: The case of Local Action Groups in Czechia. Journal of Language and Politics, 15(6), 768-789. DOI: $10.1075 / \mathrm{j}$ p.15.6.06sem.

[28] Šifta, M. \& Chromý, P. (2017). The importance of symbols in the region formation process. Norsk Geografisk Tidsskrift 71(2), 98-113. DOI: 10.1080/00291951.2017.1317285.

[29] Svobodová, H. (2015). Do the Czech Local Action Groups Respect the LEADER Method? Acta Universitatis Agriculturae et Silviculturae Mendelianae Brunensis 63(5), 1769-1777. DOI: 10.11118/actaun201563051769.

[30] Tácsik, B. (2009). Ipoly-menti Palócok Helyi Közösség genezise. Különös tekintettel a Belső - Cserhát vidékre és a LEADER megközelítés szerepére [MA thesis]. Eger: Eszterházy Károly Föiskola.

[31] Thuesen, A. A. (2009). Is LEADER Elitist or Inclusive? Composition of Danish LAG Boards in the 2007-2013 Rural Development and Fisheries Programmes, Sociologia Ruralis, 50(1), 31-45. DOI: 10.1111/j.1467-9523.2009.00500.x. 
[32] AEID (1994). LEADER Directory of the 217 Local Action Groups. LEADER Coordinating Unit. $470 \mathrm{p}$.

[33] Brosei, P. (2011). The principles of the Leader approach: lessons learned and future potential for local rural development. European Economic and Social Committee Public Hearing "Leader as a tool for local development" 20 June 2011 [unpublished presentation]. Retrieved from http://www.eesc.europa.eu/resources/docs/leader-2062011---mr-brosei.pdf (Last access: 7 March 2017)

[34] Brosei, P. (2012). Multi-level governance in LEADER and lessons learned from the implementation. Open Days 2012, 11 October, European Commission DG AGRI Unit "Consistency of rural development" [unpublished presentation]. Retrieved from http://enrd.ec.europa.eu/enrd-static/fms/pdf/54EB3377-0A21-52D3-2350EAC29951DBC1.pdf (Last access 3 Sept 2014).

[35] Fekete, G. É. (2014). Helyi termékek a helyi gazdaságfejlesztésben. Presentation at VII. Magyar Földrajzi Konferencia, Miskolc-Lillafüred 2014.09.02.

[36] Lechner Nonprofit Kft. (2015). Nemzeti LEADER Kézikönyv. LEADER Helyi Fejlesztési Stratégia Tervezési Útmutató 2014-2020. Miniszterelnökség Agrár-Vidékfejlesztési Programokért Felelős Helyettes Államtitkárság.

[37] Nemes, G. (2005). Az előcsatlakozási programok (SAPARD, PHARE, ISPA) tapasztalatai. AVOP LEADER+ készségek elsajátítása tananyag, PROMEI-Falumühely AlapítványSZRVA-ZRVA, 2005 9.1. fejezet (pp. 316-336) http://www.promei.hu/index.php?m=1134\&id=1066.

[38] ÚMVP (2013). A helyi akciócsoportok munkaszervezeteinek elérhetősége. http://umvp.eu/?q=node/645

LEADER_HACS_elérhetőségek_2012_11_ho_IH_orszagos.xls (20 September 2014).

[39] 1312/2016. (VI. 13.) Korm. határozat a központi hivatalok és a költségvetési szervi formában működő minisztériumi háttérintézmények felülvizsgálatával kapcsolatos intézkedésekről. 